\title{
Reflection and Diffusion of Mbaise Culture through African Traditional Music: Abigbo Musicians' Social Responsibility Model
}

\author{
Okoro, Justice Chukwudi (Ph.D.) \\ Department of Music, Faculty of Arts, Delta State University Abraka, Delta State, Nigeria
}

\begin{abstract}
The study of Abigbo musical development in a rural setting aims at creating awareness on the functional values of a traditional Igbo customary music performance practice. It appends more recognition to African music demands as it affects a homogeneous society such as Mbaise. Through this study, new generation and posterity of African music researchers will encounter wider range of reference material to justify their African music research interest. This is possible as the work draws attention to attributes typical of Abigbo which serve as basic challenges to limited residual knowledge of African music. The work further unfolds traces of peculiar ethnomusicological thoughts inspired by captivating musical ideas propagated in Abigbo. It facilitates the appreciation of African musical touch divorced from Western or Euro-American music dominant influence. This is evident in the insight it provides on how and why Abigbo makes a showcase of the indigenous lifestyle in the course of its rendition. By exploring music creative possibilities and the fundamental skills in Abigbo verbal and instrumental communication, the study serves as a springboard for new learning, cross-cultural interactions and broad societal focus on African traditional music. This indispensably makes a broad-minded society open to unlimited ideas of music in local tradition. Thus, negligence of such an aboriginal African folk communities musical heritage and resorting to any other readily available pieces of domestic but foreign music that make immediate appeal to the indigenes is contrary to Abigbo musicians' role model in Mbaise. In another development, Uzoigwe's research on Ukom references Abigbo musical functions with predominant emphasis on the areas of aged women interment rites, marriage issues and unnamed celebration of daily affairs. By these hanging statement of claims, he considered Abigbo music only strictly or majorly for checking marital misconducts in all their ramifications; gracing of adult feminine burial ceremonies et alia. This part-reference resolve can be misleading and therefore needs further inquisition through this scholarly review. Doing so will provide guidelines for adjustment and development that reflect the true position of Abigbo in Mbaise scheme of things.
\end{abstract}

Keywords: Reflection and Diffusion, African culture, Traditional music(ians), Abigbo, Mbaise, Social responsibility

Publication date:September $30^{\text {th }} 2020$

DOI: $10.7176 / \mathrm{ADS} / 85-01$

\section{Introduction}

Abigbo primarily emanated to approach its indigenous audience and expose them to a worthwhile musical performance inculcated in it through stimulative creativity. However, in the process of practicing its vocational adroitness as and when due, a crop of modern Abigbo musicians' ignorant posture towards the concept of musicianship has to some extent wrestled with these objectives. The aforementioned plights pose great challenge to Abigbo and as such call for scholarly investigation and subsequent amelioration through devotedly explored informed research. More so, the facilitators of music globalization, which encompass the print media, the conglomeration of electronic media such as the computer website and documentaries have so displayed the music of other cultures of the world with scarcity of functional, modern and durable gadgetry, to support dutiful promotion of Africa ensemble's musical endeavour that musical events no longer generate requisite culture shock to the public audience. Consequent upon the above factor, those that used to be overwhelmed by music acculturation witnessed on both 'paper and the screen' become biased against Abigbo music and similarly become disgruntled with what they consider as queer ideologies inherent in it. Besides, varieties of Abigbo musical activities heard and watched with keenly interest usually display talented artistes whose expertly creative endowment has not been duly scrutinized for documentation. This grouse can subject the ensemble to a subject of absurdity if care is not taken to correct the gruesome impressions. These series of unfounded allegations in opposition to Abigbo are hurdles such speculations invariably append to the appreciation of the traditional music (as both a discipline and a way of life) in the community as a whole. The after-effects of the aforementioned gossips altogether, subsequently motivate this ethnomusicological research.

In the cosmic comity of nations, certain musical genres have their pride of place which enables them resist extinction and alternatively stand the test of time. Leaving Abigbo out in this universal trend of publicizing music somewhat leaves much to be desired. The attributes of Abigbo including its rendition techniques are faced 
with many a challenge arising from commentary by handful of Mbaise sojourners and the residents of her environs. Hearsay on Abigbo by those that question its role model in Mbaise label it a counter-productive venture, sheer inanities, formidably uncivilized and morally unworthy of tolerance. Worse still, the critics' condemnation of the art (which is a concomitant of their prejudice towards the ensemble) may not only cripple Abigbo the more and expose it to ridicule but also can provoke dearth of membership recruitment and invariably render the musicians impecunious if efforts are not made to nullify their assumptions with proof on the true position of Abigbo. Other problematic observations constituting cruxes for enquiry and satisfactory solution, which necessitate this study, are some biased indigenous presumptive remarks militating against Abigbo. These have rather led to withdrawal attitude among the performing arts enthusiasts who are inclined in Abigbo Mbaise. Thus, suffice it to say that for its wider social awareness the logically enviable concepts of Abigbo and all it encompasses, in no small measure, call for evaluation through research findings

To this end, to actualize socio-economic, political, spiritual, educational and cultural growth in the interest of Mbaise society, salient problems given a pride of place by addressing them in this work are: how indigenous knowledge, philosophy and theory are reflected in Abigbo to promote succor, social co-operation, progress, solidarity, understanding, peace and unity founded on equity for people's welfare. The study concludes with principles instrumental in ideal service to the people; communication network established with good rapport borne out of peaceful co-existence in neighborliness evident in Abigbo role model. For this proposal to come to pass, the consciousness of the ensemble has to be focused on how to speak for the people, sustain their collective identity, cultural heritage and oversee their inheritance. This calls for guarding against lax issues in favour of those of common interest among the people. It also entails quick response to a clarion call for service void of selfishness. Suffice it therefore to resolve that Abigbo deserves to be adequately and continually fostered against all odds if not, it may become extinct, in lieu of a leading recreation art that it has been in Mbaise.

\section{Attributes of Traditional Music (ians) in African Context}

Traditional music in many ways represents continuity with indigenous history and gives us an opportunity of learning about the present state of music in a given milieu. Amuchie in Oguoma (2010:138) describes traditional music as "Music controlled by situation since it can emanate spontaneously from individual or group that is inspired by the occasion, and so becomes a communal property."Amuchie's view is justifiable because music rendition is situation-motivated. "Traditional Music represents the people's way of life being an integral part of their culture" (Oguoma, 2010:138). These view presents traditional music as one rooted in culture where it is mostly known and practised accordingly. Music, particularly the traditional genre, is inevitable because with it, cordial relationship for peaceful co-existence is learnt in order to fit in within the societal context. "Traditional music," according to Nzewi (1977:98), "is judged not by its quality as an interpretative reproduction of a fixed composition, rather by its interest as a fresh composition that is, as a contextual re-composition of a model format." This stands to reason that it is a re-composed piece of existing music within a social context. Okafor in Agu (2006:113\& 118) affirms as follows:

In its process of evolution, traditional music generates social experiences which deeply impress on the people's experiences in their culture since it is directly associated with tradition, religious and political systems. In an ideal traditional setting, traditional music performance usually assumed the mood of a festival. Under this situation, both performers and spectators were participants. By so doing, the sense of belonging and community solidarity were heightened.

In a similar vein, Okafor (2005:87) further opines:

Traditional music is the most widely used medium of expression for all manners of occasions and at all times and periods of life. Communities manipulate it to give voice and sound to their collective thoughts, actions, and even spirituality. In this way while the people make use of the music, the music makes use of them for it places on them that imprint on the character, mien, thought and carriage, which are commonly summarized as identity...It reflects and interprets the man in a specific environment and is often the key, which opens the gates of spiritual, mental, emotional, psychological, social and mystic realms.

Traditional African musicians are mostly identified with one occupation or another. They may not be fulltime musicians but are more of folklorists through whom folk songs are preserved in oral music tradition. Such is the case with Abigbo music practitioners. Ebighigbo (2005:188) avers: "Traditional music is the music of the farmer, the fisherman, the hunter, the craftsman, the trader and the palm wine tapper, who composes, dances and transmits same to posterity through an elaborate process of socialization". Traditional music is identified here as music for the rural dwellers who eke out a living through one vocation or another.

Being music in a traditional setting, it becomes a matter of necessity to survey what obtains in African music as bedrock on which to assess Abigbo Mbaise before we can draw conclusion on its musical peculiarity. Africa, the second largest Continent (after Asia), abounds with varieties of traditional music arising precisely from the continental musical background, ideology and prevailing circumstances surrounding it. All aspects of 
African music definitely disclose parts of the people's great heritage. Sound ideals and styles in music are evidently some of these attributes, whether musicians can verbalize them or not.

A good understanding of African music in relation to factors affecting its traditional traits entails an examination of the organ, evolution, distribution and geo-political description.Beyond this affirmation, "the musical patterns of any social group unfold a true index of their attitude, personality, historical evolutions, the continuity of their existence and the horizon for which they are set" (Okafor, 2005:88). To Tracy (in Akpabot, 1986:40), music in Africa means "vocal participation, the physical manifestation of instruments and the rhythmic or dance movement associated with music." Here, we can deduce that voice, instruments and dance are the basic components of African music. All other musical factors - props, costumes, etc. are complementary. Waterman in Merriam (1959:65) tells us that it would be wiser to speak of "African music as percussive, rather than to emphasize the use of percussion instruments exclusively. The trough zither (East-Africa) for example, is used to produce music which is clearly percussive in effect, though it can in no sense be called idiophone or membranophone". This affirmation is true because trumpets of many kinds are played for percussive impact, though the notes are melodic. Nketia's (1975:4) position on African music includes "those that not only have their historical roots in the soil of Africa, but which also form a network of distinct yet related traditions which overlaps in certain aspects of style, practice or usage, and share common features or internal pattern, basic procedure, and contextual similarities". Nketia by implication rules out total belief that the venue or geographical location where a given musical genre is composed or performed is strictly the music bona fide. Rather, what matter most are the musical performance styles and features as well as instruments involved in the music making. These are considered in relation to a social culture to determine the true ownership of the music. Structurally, five points general features representing stable aspects of African musical culture are - "Metronome sense, dominance of percussion, polymeter, off-beat phrasing of melodic accents, and overlapping call-and response patterns" (Merriam, 1959:76).

"African music is the indigenous music of the people which forms an integral part of their way of life" (Nzewi, 1980:12). This is because the people's conventions and constitutions altogether govern African music. "African indigenous music products derive from rich and unique creative philosophy and theory, which inform the systematic structural ramifications, compositional principles, ensemble process and distinct vocal and instrumental idioms" (Nzewi, 2005:69). That is why the music reflects their norms and values. Because music in Africa is integrated into their daily life, a large number of people therefore participate in, and enjoy musical activities. The separation of the 'artistes' from the 'audience' is not traditionally African - Although specialists are always present, music is participatory. Hence, a musicological school of thought is of the opinion that the type of audience influences musical "shape, vitality and dynamism" while "environment, audience and occasion" determine the artistes' emotional application to extemporization to achieve a smooth and graceful motion in musical duration and content. ;" Euba (1986:46) recognizes that culturally, "the content and context of African music always suggest open-air performances where the performers show proof of their nationalities through their performances and clamour for audience admiration, they reveal most of their traditional values to outsiders. By implication, cultural transfer is optimally maximized in African music performances". With this understanding, Nketia (1975:240) in consonance with Euba's subject matter concludes, "although traditional music is performed on social occasions, there are norms that must be observed, expressions that must be fulfilled."

\section{The Place and Essence of Culture in Mbaise}

Culture is inevitably discussed in this study with reference to, and in the context of its social environment where Abigbo is prevalently practised. It is also defined with the view to understanding its unique roles and importance in a homogenous and communal setting such as Mbaise, a microcosm of Africa culture. Heterogeneous culture also exists in a complex social environment, which is typical of Africa.

Emeka (2004:277) defines culture under environmental setting as:

The cumulative experience of a people in their years of systematic attempts to master their environment so that they can enjoy a higher quality of life. As the man - made part of the environment, it is central to life in a human society. It is dynamic so that it can cope with changing and challengeable environments. It is experience which implicates change and continuity. Provided that it is open to constructive new ideas, culture offers the best accommodation for high quality of life while still maintaining the equilibrium in a human society.

The meaning of 'culture is never affected by situations and circumstances. Taylor (1871) in Holton (1965:24) defines 'culture' as "The complex whole, which includes knowledge, belief, art, law, morale, custom and many other capabilities of man as a member of society."Cappalletti (1971:13) averse, "culture is the awareness possessed by a human community of its own historical evolution by reference of which it tends to assert continuity of its own being, and to ensure its development."Mairi (1965:8) tells us thus, "A culture is the common possession of a body of people who share the same tradition in social terms." To Knickohn in Ukeje (1979:371), "culture is the part of learned behaviour which is shared with others". The Constitution of Federal 
Republic of Nigeria (F. R. N.) on Cultural Policy for Nigeria (1988:5) defines culture as "the totality of the way of life evolved by a people in their attempts to meet the challenge of living in their environment, which gives order and meaning to their social, political, economic, aesthetic and religious norms and values of organization thus distinguishing a people from their neighbours". Bodley (2009) considers 'culture' as "the patterns of behaviour and thinking that people living in a social group learn, create and share."

Hunter Encyclopedia of Anthropology (1976:103) is of the view that "culture is the patterned behaviour learned by each individual from the day of birth as he or she is educated (socialized and enculturated) by parents, and peers to become, and remain a member of the particular group into which he or she was born or joined."Consequently society and culture are inseparable because the inhabitants of a society derive from its culture what such a society can be singled out with as their peculiar identity when compared with others. In keeping with that, Good's Dictionary (1959) idea of culture is - "the aggregate of the social, ethical, intellectual, artistic, governmental and industrial attainments characteristic of a group, state or nation by which it can be distinguished from and compared with other groups or nation." The latest definition justifies culture as a mark of identity for a social group, which sets them apart from others. As an integral part of a people's life, it is therefore very vital that culture should be propagated to ensure that the people develop with a sense of dignity and personality. "A culture transmitted is a culture perpetuated and that is the surest way of ensuring cultural continuity. This further creates a situation of intercultural transfer, or give and take relationship.

Culture varies from one society to another and is subject to change with time over years. According to Quillan and Hanna in Ukeje (1979:371), "culture includes both the behaviour which an individual learns by living in a particular group and the man-made things - or artifacts - which are the products of learned behaviour." By this definition, the people's culture comprises ideas, habits, values, beliefs, customs, inherited artifacts, goods, skills or technical processes and all the characteristic activities and interest of the people. It exists in human environment as the total way of life, which differentiates a human race from another, and by which it can be likened one to the other. Okafor and Emeka (2004:57 and 59) speak volumes for this resolve as they affirm: "Culture determines the normative, cognitive, value, production and authoritative systems of a society... determines the real ways of life, and members of that society try to modify it over a long period of time... It regulates the standard by which members of a community live as well as interact among its members and components." That the essential mechanism of social order is strictly justified by cultural conventions and customs is resolutely a given. "Culture dictates the success or failure, confirming and non conformity, the rights and the wrongs, the acceptable and the distasteful, relating to the governing thoughts, words and deeds by members of the group" (20). In the long run, culture distinguishes the people from, or compares them to others based on the uniqueness of their social know-how; recognizes, and characterizes them notwithstanding that they originated it. Gustav Klama in Okafor and Emeka (2004:12), defines culture as "the customs, information and skill in domestic and public life, in peace and war, religion, science and arts, which manifest in the transmission of past experience to the new generation."Thus, all things material and otherwise, invented or made by mankind such as the fabric of ideas, believe system (religion and superstitions), tools, methods of cogitating, aesthetic objects, institutions and customs - where each member of the society is born - collectively constitutes culture.

Culture in performance creativity (such as Abigbo) has to do with “.... people's literature oral or written, as well as their visual and performing arts, which are normally moulded by, as well as help to mould other aspects of culture" (FRN, 1988:5). Putting into consideration human artistry, it is simpler and clearer to define culture as "all the knowledge, beliefs, customs, values, ideas, and skills available in a society and by which the society can be compared to or differentiated from others"(Okafor and Emeka, 2004:14). Akpabot (1986:91), a Nigerian musicologist par excellence sums it up this way: "Culture we know to be a way of thinking, feeling and behaving in a given society resulting in a behavioural pattern which gives that society a distinctive identity." Giving that Akpabot's definition is a product of "enculturation" expertly defined from ethno-communal perspective, and the scholar's indigenous geographical location being proximate to the researcher's native land, we therefore consider his definition most apt yardstick to justify the involvement of Abigbo musical genre in Mbaise culture in this study.

Onwuejeogwu $(1987,1973)$ in Egbule $(2006: 3)$ avers, "culture area is a geographical delimitation of areas that have the same dominant and significant culture traits, complexes and patterns."Traditionally, Mbaise culture area is akin to Igbo customs though with a few variations. "The cola nut customs, music, dance, art, oral literature, ethics, philosophy and ritual avoidance and taboo are basically patterned to reflect an identical conception of Igbo social and ritual systems" (Egbule, 2006:6). All these are, to a large extent, culturally observed in Mbaise community through Abigbo.

Mbaise strongly believes that "culture is half - way" (George Meredith, 1895), and that "man is born a barbarian and only raises himself above the beast in culture" (Balthazar Srecian, 1647). Guided by the aforesaid view as Agulanna (2009:219) records it, the diversity of Mbaise enabled her produce people who revolutionized culture in the folk community. The son of the soil, the late Ambassador Gaius Anoka created the Omenimo Dance Troupe and started the Mbari open air Museum cited in Ikenegbu layout, Owerri. He equally initiated the 
popular Ahiajoku lecture which brings together the whole Igbo tribe to discuss the survival and continuity of the Igbo tradition. A major cultural event in Mbaise is the Oji (kola) Ezinihite. It expresses cultural values of honesty, fairness, justice and reliability. All these represent $O f o n a O g u$ which is needed to reinforce the cannons of existence in the community. Through Aladimma the injunction of Onyeaghalanwanneya is revamped. Land tenure in Mbaise is bequeathed through inheritance. The origin, acquisition and transfer of land is not properly documented.

The diverseness of Mbaise society is captured and encapsulated in their resilience (Ishi onwu): industry (Igbambo); Competitiveness (Ndoli); perseverance (Ikweonwu); diligence; burning determination to succeed; enterprise; push; drive; dynamism; and being studious (Igu akwukwo). It means jack-of-all-trades; maid-of-allwork; human dynamic; busy bee; work horse and willing horse. It represents high fecundity (Igbuewu - ukwu); fraternal affinity (Ikwa Ibo) during external threats leading to soldier ant (Ijere) mentality. Mbaise also means abundance of cultural dances and songs; self - development oriented. It also means the ability to tap palm wine and process the best oil bean (Ugba), (Agulanna, 2009:213).

Generally speaking, going by the federal government promulgation of cultural policy for Nigeria in 1988, technology, education, tourism and industry are considered the primary foundation of her cultural development. This truism applies to Mbaise as the 'microcosm' of Nigeria. The people's development is more purposive because it is integrated to cultural promotion. Their environmental social qualities emanate from, and incline to the impacts of cultural traits on them. Thus, their peculiar response to many facets of environmental diversities and dynamic varieties constitute their entire concept of life. According to them, "the experience of each generation"- matching reactions aftermath- "are transmitted to the succeeding generation which uses them to build upon and create its own legacy" (83).

According to Nwala and recorded by Onyegbaduo (2009:69), "As should be experienced, they presented a type of culture, social consciousness and characters which was quite rural, troublesome and unpolished. Tragically, non - Mbaise elements saw these as all of what Mbaise could offer in the way of character and stuff." However, if this was true then, it is not so today. It is this age-old misconception that has trapped the people's critics. Some Mbaise natives are among the best bred, most refined, resilient and reliable Nigerians in all disciplines and professions. This has indeed become a new source of envy. Onyegbaduo (2009:47) amplifies this as he says inter alia: Mbaise suffers tremendously from bad image, which the name evokes negatively in the mind of people. It represents somebody evil; a people you can't deal with because they are untrustworthy and terrible; predators and all such unimaginable characterization. Mbaise natives are treated condescendingly based on these unsubstantiated and mostly foolish stereotyping. Even some policy makers have been misguided in basing their treatment of Mbaise indigenes on this dangerous denigration.

In their individual identity, they could stand distinct in certain cultural practices, be it norms, values, or even belief system. However, in the course of time coupled with enlightenment through acculturation, socialization and western civilization, the people discovered and embraced unity in diversity. Under the exotic issues or circumstances of life confronting Mbaise of those days, Onyegbaduo's (2009:47\& 49) impression of Mbaise culture reads thus: "In a world of turmoil, culture is the most potent moderating influence. In times of trial, culture offers an umbrella of protection. It is the compass with which a people can find their way out of the wilderness of economic despair, political anxiety and social disintegration." However, seeing the present Mbaise as an organized autonomous society he concludes: "Mbaise has a culture of disciplined society. In the past we had the 'Okonko' which imposed law and order in the society. Although 'Okonko' lost out to colonial Christian onslaught, today the discipline of our communities is organized along the 'Aladimma' system. The advantage 'Aladimma' has over urban disciplinary machinery is that everybody is known to everyone else. It is not easy to hide under any anonymity to commit crime, or breach the taboos and norms of the people".

Promotion of literacy through formal training is highly encouraged in Mbaise. Unalloyed embrace of western education enables them produce highly educated persons within various fields of human endeavour and put them in good stead to occupy sensitive positions in government, the academia and in other walks of life. Their great strides of the past did translate into physical/economic development of the area, and enabled them lead in several spheres of their polity. The Mbaise are highly religious and are adherents of both traditional and Christian religions. Before the introduction of Christianity into Igbo land, it was the common practice for an Mbaise male adult at dawn to pray beckoning on $O f_{o}$ and $O g u$ symbolic deities of retributive justice to protectively avenge the innocence. The said male adult does this soliciting for assistance and deliverance from contrary forces, so that he can subdue his antagonists in times of crisis. Before this prayer session, he conjures up the spirit of the ancestors to come; at this juncture, cola nuts are offered for Mbaise's longevity because of the belief that he who brings cola brings life. All these are done in a private 'altar' in the home to guide against distractions. It is believed that for the invocatory prayers and supplication to receive favourable answer, it must be in concordance with the customary ethics. That is why one has to retrace one's steps before undertaking such an oath so that it will not boomerang. With this development, the indigenes were mindful of their deeds. However, the advent of Christianity in Mbaise has, to a large extent, eradicated traditional religious practices. 


\section{Theoretical Framework.}

This study anchors on the Social Responsibility Theory (S.R.T.) propounded by Theodore Peterson. The theory emanated consequent upon social injustice, marginalization, humiliation, segregation as well as disparities evident in colour discrimination which were the order of the day in the history of the United States of America. It explicates cordial interaction among different members of the U.S.A. believing that such rapport in social relationship necessitates provision of interpersonal communication which may not necessarily be face-to-face.

The S.R.T. equally necessitated the involvement of W.E. Hocking's commission of enquiry, which was then put in place as an added weapon in pursuit of good human relations and equal rights. To this effect, Bo and Nyitse (2009:149) report that the commission was charged to collaborate with the media in the responsibility of "presenting and clarifying goals and values of societal daily events with a truthful, comprehensive and an intelligent account in a context which gives them meaning; serving as a forum commissioned for the exchange of critical comments while providing and presenting a representative picture of the constituent groups in society". To realize this objective according to Siebert (1956:85-87), the commission urged the American Society of Newspaper Editors and News Reporters to "practice responsibility to the general welfare, sincerity, truthfulness, impartiality, fair play, decency and respect for the individuals...the news agency must not only avoid departing from the truth but also have to be accurate in identifying and projecting facts and opinions." This move, according to him, involves introspection.

In the light of freedom of expression, the Social Responsibility Theory is of the view that it is naturally a moral and universal right for all with an aspect of man's duty to his thought and action grounded on its utility S.R.T. Assumes that the search for the truth and its spread when found requires considerable freedom void of the right to err. However, the theory admits that trial and error arising from experimental liberty can be excused. This presupposes that moral right for free expressions covers only honest mistakes. The Theory considers it imperative for the 'mass communicator' to link moral rights and duties to his own conscience. That is why freedom of expression is practically and unconditionally witnessed in Abigbo social responsibilty. In this case, the musicians as the watch dog in Mbaise society are by obligation expected to reflect and diffuse the people's culture with their traditional music, and should do so with diplomacy, sincerity of purpose, fellow feeling, sense of humor, responsibility, belonging, and of course, sensitivity.

\section{Abigbo's Mutual Interaction with Mbaise Belief System}

Our concern here is strictly to evaluate Abigbo's activity in Mbaise under the influence of their dual interrelationship with each other. In furtherance, the study equally typifies cultural revival through mutual interaction between Abigbo and Mbaise. Other matters arising from the above affirmation are strictly considered here as they inevitably affect Abigbo to shape its artistic rendition in the interest of the populace. The societal usefulness of Abigbo is evident in its people welfare-oriented roles in Mbaise. To appreciate these values therein entails namely: appraisal of Mbaise indigenous concept of life vis-a-vis how it impacts on Abigbo music dissemination; attributes, occasion of performance with people's interest and support as well as models of Abigbo performance platforms. These are reviewed here with special attention drawn to infrastructures for societal development. All this collectively affirms of the essence of Abigbo in Mbaise and the need to nurture its concomitants of musical art with deserved attention.

A musician as a music maker is defined by Ipere (2010) in Idamoyibo (2006:142) as "One who puts together musical resources and ideas that become an original composition or copyright arrangement intended to be presented to an audience." In consonance with Ibekwe's (2010:35) trend of thought, "a musician is a person who involves himself or herself in music making and above all takes it as a career". By extension of the conceptual definition, a musician can be a composer, a vocalist or an instrumentalist keenly involved in musicianship. Someone's eligibility in musical rendition qualifies him to bear the valid claims and fame of being addressed as a musician. Such ones, especially the master musicians, are therefore expected to inspire, impress, express, move and evoke others with the music. Beyond that, musicians are those capable of creating sounds agreeable to the ears for the upliftment of human souls. Abigbo music makers fit in here. According to Okafor (2005b:136), "Life in the village without musicians is not to be considered, and people spoke of leaving the village where no musicians are present... without musicians a village is incomplete; people want to sing and dance, and a number of village activities cannot be carried out without musicians." Therefore, "To understand the test of the members of the society in which oral literature flourishes is to understand the principles and expectations which the traditional oral artist aspires to measure up to or even to transcend in his works" (Azuonye, 2008:73).

Music is, of course, a 'cultural expression'; every culture not only gives music its definition but also decides for itself what is musical or not. Akpabot (1986:88) affirms: "Culture as we know, embraces many aspects of human existence, but perhaps in no better way is it expressed than in music and the art... One method of finding out about the culture of a people is to examine how they conceptualize their music" (91). Musical culture affects our thought, feelings and regulates the lives of the people. The behavioural pattern of a given society is, to a 
large extent, dependent upon their musical concepts. Thus, music behaviour of a particular society causes them to react in a certain way distinct from others. Floyd (1999) in Seachrist (2005:48) stresses that "each cultural and geographical area deals with the organization of sound differently.... One must work with sounds not just ideas about sound." This is because working with sound implicates creating better understanding and appreciation of cultural differences embedded in the very piece of music. To decode this entails intensive listening attitude. Analogous to this affirmation is Merriam's (1959:86) emphatic remark that "the study of music can also yield information on problems of cultural patterning, diffusion, and acculturation. Clark (1922:155) on the other hand argues, "Music is a stable cultural trait and therefore provides a useful bases for determining the diffusion of other cultural traits".

Thought sequel to an action in performance creativity differs from one community to another. For instance, "Concepts of music sound will determine the reaction of an audience to a performer in any African setting, this reaction is fed back to the performer who in turn reacts in a particular way" (Akpabot, 1986:41). Again, when disappointed by an ineligible performer, the audience react to the performance fiasco "with weary faces, sighs, mass exeunt, silence or shouts of: 'That is not the proper voice', I wish Okonkwo Oko were alive, and so on" (Azuonye, 2008:78). In this thought process, Uzoigwe (1984:80) reasons that "a dirge is therefore principally limited to a community concept over funeral and the things involved hinge on or mark the accomplishment of the dead. In this case, the soloist commences the elegy first by borrowing from the chief mourner's narrative like lamentation tales." The master drummer also imitates these woeful cries so-realized and transmits it through drum beats (musical sound) to draw the attention of the neighbourhood. To achieve this set objective, "Naturally, in an oral tradition, a great deal of attention is paid to the quality of the poet-singer's voice. An inaudible voice in an oral poem is as bad as an illegible script. Thus, many singers frequently boast about the quality of their voices" (Azuonye, 2008:97). This is considered by recruiters in Abigbo recruitment exercise.

In Mbaise, Abigbo music is one of the widely practised and communally shared arts. It reflects the people's value system and is distinct from the music forms of the other Igbo societies. Many a time, the music is ongoing to grace an occasion unless the citizenry are asleep. Okafor $(2005: 276)$ further justifies this as he comments: "within narrower confines, political, social, economic and self - interest groups always use music to rally round and to express their feelings, to mobilize their members and to generate sympathy and activity in the society". Beyond that, the ensemble's idea of music commonly signifies a basic psychological pattern of life expressions. As a popular musical activity, Abigbo not only transmits culture in Mbaise but equally helps it endure for generation. The cultural admission of trainees into Abigbo is strictly implemented with the view to enabling them learn how to ruminate and musically act in conventional ways in order to be approved within the context of the ensemble. Because Abigbo is not specifically full-time profession-oriented business, if the music is organized to grace social event, even the artistes become part of the audience. Abigbo Musicians draw audience's attention to certain socio-environmental factors affecting their musical creativity. Their compassionate appeal usually meet with some individual's solicitous response shown in cash or kind. "The calibre of individuals or their social status plays significant roles in Abigbo musical activities. These roles have impacts on both musical production and its presentation. A course of musical events may be changed or displaced by people's decision, which may be outside the direct control of the musicians themselves" (Uzoigwe, 1984:80).

Uzoigwe's idea of "hierarchical level of creativity" (80) - the sequential process of activity - implies that the event situation necessitating performance conducts are classified in their order of importance at every stage. According to him, the funeral, a behaviour or an attitude of the mind among other things, explains the community concept of death to those present as the music objectively forges ahead. The essence of their life existence is disclosed and interpreted through the ceremonial music repertoire text, dance, and drama employed in Abigbo. This is more so, whereby the musical instruments are linqua - tuned and therefore, textually sung. The concept of demise demands that, rituals are performed to the ancestors for them to welcome the dead. This is accompanied by a dirge type which could be static. The funeral is a concept realized in the course of performance by the musical group. However, the soloist commences the music first by borrowing from what the bereaved were lamenting on while crying. The thought of the community is considered by the musicians in their music. That is, they do not just play as they wish. What Uzoigwe calls "Operation level of creativity" occurs from 'conception' held in the community and how activities are carried out (i.e. cause and effect). This study is of the view that although musicians generally base Ihu-nkwa(the first movement or prelude in) Abigbo on a specific theme, it is not uncommon to observe the influence of Mbaise social environment on the music as presented in his research report. We can at this juncture deduce that conscious effort precedes any Abigbo composition for a particular social event.

\section{Conclusion}

As a performer's style in Abigbo varies from one another's, considering individual musical experience and taste, choice of the elements of music to play or dance to its sonic effect, performance skill, interpretation, including emotional expressions and, of course, aural perception endowment, so is the tone quality of every musical 
instrument (integrated in the ensemble's instrumentation) peculiar to it. Within the stage geography of the performance presentation, Abigbo performance-wise exercises the indigenes' belief, affection, artistic imagination, values and other related social identities. They do so in order to perpetuate these variable healthy cultural heritages.

However, scarcity of promoters, incompetent mentors leading to half-baked apprenticeship and inadequate incentives for performance continuity collectively makes live performance of Abigbo minimally counterproductive. Dilly-dallies in the promotion of intellectual creative initiatives for the sustenance of audience's interest thereby advancing indigenous knowledge of the art; general absence of sensitization in Abigbo altogether poses draw-back to its popularity par excellence. Conducive performance presentation environment, adept training cum sponsorship of both performers and composers of the musical art have not been given deserved attention. Above all, relenting postures of governmental agencies responsible for arts and cultural policy implementation coupled with high rate of piracy in Nigeria music industry are contributory factors to the plights so-identified.

Foreign-oriented media practitioners are equally blamed for this prevalent creative apathy and cultural alienation. Because they lack artistic imagination or theoretical insight in Abigbo, their news report on such art rendition do not strive for its continuum. More so, the musicians are not formally trained to read music from the score. On the whole however, the intended result in this study is eventually achieved by affirming Abigbo's unique artistry and establishing its associated invaluable roles of showcasing and spreading Mbaise indigenous culture.

\section{References}

Agu, D. C. (2006a). Continuity, innovation and change in Nigerian traditional music practices: The implications on national development in Abraka Studies in African Arts: African Arts and National Development. Ibadan: Kraft Books Ltd, $113-120$.

Agulanna, E.C. (2009). Mbaise in diversity in Towards Greater Mbaise. Lagos: Clean Foundation Resource Centre, $212-226$

Akpabot, S.E. (1986). Foundation of Nigerian traditional music. Ibadan: Spectrum Books, (Nig.) Ltd.

Azuonye, C. (2008). Principles of the Igbo oral epic: A study in traditional aesthetic and oral literary criticism G.G. Darah (ed.) in Radical Essays on Nigerian Literature. Lagos: Malthouse Press Limited, 73 - 104.

Bodley, J.H. (2009). Culture. Redmond, Microsoft encarta [D.V.D.] Microsoft Corporation Retrieved: June 25, 2013.

Cappalletti, V. (1971). Cultural policy in Italy: UNESCO Publication. https://en.unesco.org>creativity>policy

Clark, W. (1922). The American Indian. New York: Oxford University Press.

Ebighigbo, C. (2005). Some aspects of unexplored African music: The Igbo flute (OJA) in ceremonial situations in Nigerian Musicological Journal. 1(1), 184 - 194

Egbule, P.E. (2006). Synergy, cultural relations and development in Igboland. A lecture delivered at the annual celebration/end of year party of ELOBUIKE,(an association of Igbo senior staff of Delta State University, Abraka, Nigeria.) Dec. 10, $1-15$.

Emeka, N. L. (2004c). Triangle of progress of development, culture and communication" in Nigerian Peoples and Culture ( $4^{\text {th }}$ ed.). Enugu: New Generation Books, $273-296$.

Floyd, S.A. Jr., (ed.) (1999). International dictionary of black composers. Chicago: Fitzroy Dearborn. https://catalogue.nla.gov.au

Eric B, (ed.). (1954). (5 $5^{\text {th }}$ ed.). Grove's dictionary of music and musician. 7, New York: St. Martin's Press, Inc. https://amazon.com

Holton, G. (1965). Science and culture: A study of cohesive and disjunctive forces. Cambridge: The Riverside Press, Houghton Mifflin Co. https://amazon.com

Hunter, D.E. \& Whitten, P. (eds.). (1976). Culture in harvard world encyclopedia of anthropology. New York: Harper \& Row Publishers Inc.

Ibekwe, E.U. (2010b). Music and the philosophical dimension of African man in Awka Journal of Research in Music and the Arts (A.J.R.M.A.), 7, 22 - 32.

Idamoyibo, I.O. (2006). The musician as a mass communicator: The voice that leads the way to national development in Abraka Studies in African Arts 1, African Arts and National Development. Ibadan: Kraft Books Ltd. $141-148$

Mairi, L. (1965). An introduction to social anthropology. Oxford: The Claredon Press.

Merriam, A.P. (1959). African music: Continuity and change in African cultures. Vits (ed.). Chicago: University of Chicago Press

Nketia, J.H.K. (1975). The music of Africa. London: Mgbo Publications Limited.

Nzewi, M. (1977). Master musicians and the music of Ukom, Ese, and Mgba ensemble in Ngwa, Igbo society. Ph.D. Thesis: Belfast, Queen's University. 
Nzewi, M. (1980) Folk music in Nigeria: A communion in Journal of International Library of African Music, 6, (1), $6-21$.

Nzewi, M. (2005). Modern art in Africa: Whose modernism? In multiple interpretation of dynamics of creativity and knowledge in African music traditions Dor and Omojola (eds.). U.S.A.: Music Research Institute, 59 79.

Oguoma, P.A. (2010). Owerri traditional music performance: A social melting pot for human development in Awka Journal of Research in Music and the Arts (A.J.R.M.A.), 7, 136 - 153.

Okafor, R.C. (2005b). Music in Nigerian society. Enugu: New Generation Books.

Okafor, R.C. \& Emeka, L.N. (2004). Nigerian peoples and culture. Enugu: New Generation Books.

Onwuejeogwu, (1987). Evolutionary trend in the history of the development of the Igbo civilization: The culture theatre of Igboland in southern Nigeria. A paper delivered in Ahiajoku lecture held in Owerri culture division, ministry of information and culture. (no pages).

Onyegbaduo, P.J. (2009a). The Mbaise world view in contemporary Nigeria in Towards Greater Mbaise. Lagos: Clean Foundation Resource Centre, 45 - 56.

Siebert, F.S \& Theodore, P.W. (1956), Social responsibility theory, Urbana: University of Illinois Press. https://scribd.com/document/309273913/social-responsibility-theory

The Constitution of Federal Republic of Nigeria on Cultural Policy for Nigeria (1988 - 1989).Lagos: Federal Government Press. https://constitution.lawnigeria.com

Ukeje, B.O. (1979). Foundation of education. Benin City: Ethiope Publishing Corporation.

Uzoigwe, J. (1984). Tonal organization in Ukom drum performance in Nigerian Magazine, 44(3), 53 - 60. 